\title{
Education for Sustainable Development: The Impact of the Values in Mobile Phone Addiction
}

\author{
Gladys Merma-Molina *, Diego Gavilán-Martín and Juan-Francisco Álvarez-Herrero
}

Citation: Merma-Molina, G.; Gavilán-Martín, D.; Álvarez-Herrero, J.-F. Education for Sustainable Development: The Impact of the Values in Mobile Phone Addiction. Sustainability 2021, 13, 1479. https://doi.org/10.3390/su13031479

Academic Editor: Jin Su Jeong Received: 14 November 2020 Accepted: 22 January 2021 Published: 1 February 2021

Publisher's Note: MDPI stays neutral with regard to jurisdictional claims in published maps and institutional affiliations.

Copyright: (c) 2021 by the authors. Licensee MDPI, Basel, Switzerland. This article is an open access article distributed under the terms and conditions of the Creative Commons Attribution (CC BY) license (https:// creativecommons.org/licenses/by/ $4.0 /)$.
Department of General and Specific Didactics, Faculty of Educacion, University of Alicante, 03690 San Vicente del Raspeig, Spain; diego.gavilan@ua.es (D.G.-M.); juanfran.alvarez@ua.es (J.-F.Á.-H.)

* Correspondence: gladys.merma@ua.es

\begin{abstract}
The key competences for sustainable development, among which is digital competence, will not be achieved without the integration of values in education. The objective of this research was to identify and analyze the relationships between the values taught in schools and mobile addiction. The study design was predictive correlational. The sample consisted of 1453 students of primary and secondary education ( $61.3 \%$ women; $38.7 \%$ men). The findings have shown a significant correlation between the values taught in schools and mobile phone addiction. It is concluded that the greater the formation of values, the less the mobile addiction. These correlations are especially significant regarding social values such as solidarity, inclusion, and justice, and personal values such as enthusiasm, patience, impartiality, openness of ideas, honesty, and balance. Likewise, there are significant differences depending on the educational stage; the younger the age, the less the mobile addiction.
\end{abstract}

Keywords: values; addiction; mobile phone; Sustainable Development Goals; adolescence

\section{Introduction}

Technologies have radically disrupted the lives of people of all ages, but especially those of young people and adolescents. The media and communication ecosystem has changed [1] and it has gone from the hegemonic model of the mass media to another model of production and dissemination of information, which is characterized by a great variety of personalized communication processes which are more horizontal, where the users decide what is worth disseminating and what is not [2]. Education has also been influenced by this model and has incorporated the development of media competence, which is based on digital competence. This includes going beyond the knowledge of the environment; that is, moving towards the development of new knowledge, skills and attitudes that enable social transformation [3-5], promoting the responsible use of technology within people's daily activities [6-8].

Technologies are also an essential ally to achieve the 17 Sustainable Development Goals (hereinafter SDG) because they have great potential to accelerate their fulfillment and reduce the cost of the implementation process. Among the benefits that they can bring, the creation of new jobs, democratized access to information, the improvement of the quality of education, the promotion of sustainable industrialization and the promotion of innovation stand out [9].

Mobile telephones are one of the technological tools that have a very important impact on the educational field, inside and outside the classroom, and that are useful for both students and teachers of all educational stages. What in previous years many internal regulations of the schools prohibited, has become today one of the most useful objects as it helps the student to engage interactively, learn and get closer to reality.

Lately experts have focused research on mobile learning. They have analyzed and explained how mobile devices allow students to access learning resources at any time and place, and have also examined their use by teachers in teaching and interactive 
tutoring $[10,11]$. However, although mobile phones have multiple benefits, especially in the educational field, specifically, in the learning outcomes [12-14], in the construction of knowledge [15], and in the increase of the students' motivation and commitment [16], their excessive use can have negative consequences in children and adolescents, both personally and in their family, academic and social life [17]. This use can also be harmful to people's health, as it can cause headaches, fatigue, concentration problems, insomnia, and visual and hearing problems [18-20]. Likewise, other authors, such as Enez et al. [21], have identified, in young people addicted to mobile phones, problems in some dimensions of personality, such as low self-esteem, introversion and loneliness.

\subsection{Research on Mobile Addiction}

The mobile phone has proliferated in recent decades due to the countless advantages it offers, such as portability and Internet surfing, as well as access to social networks, navigation systems, real time information broadcasting, cameras, and multimedia players. In Spain, according to a report by Epdata [22], 90\% of adolescents, whose ages fluctuate between 10 and 14 years, already have a smartphone. Of these, $40 \%$ of male adolescents affirm that they consult their mobile phones between 50 to 100 times a day, which means that they have active contact with their smartphone every 15 or $20 \mathrm{~min}$, and 6\% indicate that they touch the mobile about 450 times a day, which implies active contact with the device every $3 \mathrm{~min}$. For their part, $45 \%$ of women of the same age affirm that they consult their mobile phones 50 times a day, which means looking at it every half hour, and $4 \%$ of them consult their mobile phones more than 450 times a day [23]. Although there is a growing interest in investigating the influence and consequences of this excessive use in children and adolescents, its effects vary, and the real magnitude of its impact remains unclear [24].

The first investigations that raised the alarm about mobile addiction in Spain go back to the studies of Muñoz-Rivas and Agustín [25]. These authors stated that the main risk group are young people. Subsequently, there was a greater interest in investigating the symptoms and characteristics of this addiction. Subjects with this type of compulsive behavior [26] present a state of wakefulness or permanent alert towards any signal that comes from their mobile phone, which causes the uncontrolled or compulsive need to consult it constantly and anywhere [27]. All in all, this cyber addiction, which does not involve the consumption of any substance but is a behavioral addiction, is characterized mainly by a pattern of problematic use, dependence, and lack of control [28-33]. Goswami and Singh [34] point out 7 criteria for identifying mobile phone addiction: tolerance level, abstinence, non-specific use, difficulty of control, excessive time of use, interference with other activities, and continued use.

In the empirical research on the consequences of the mobile phone use in recent years, the effects observed are not homogeneous. Some argue that they have positive effects, others negative, and even a zero effect is noted $[35,36]$. Despite the variety of opinions and findings, a number of studies conclude that there is a negative relationship between mobile dependence and academic performance in both high school students [37-39] and college students [40-44]. Along these lines, Gi et al. [17] found that dependence on smart phones negatively predicted student performance in language and math. From another perspective, Beland and Murphy [45] investigated the impact of schools banning mobile phones on student test scores and found that the ban improved the results of low-performing students. Bhatt et al. [46], Han et al. [47], and Lee et al. [48] have shown that excessive mobile phone use can adversely affect the mental health and well-being of young people.

In a Spanish research study on Internet and mobile phone use among young people, Ruiz, Sánchez and Trujillo (2016) [49] found that 39.5\% of them had problems with mobile phone dependency. The authors conclude that it is fundamental to empower the role of families and educational centers to provide young people with strategies that allow them to use mobile phones in a balanced way. In relation to sex and age, according to De la Villa-Moral and Suárez [50], girls and older adolescents suffer more problems related to mobile phone use. 
In short, the growing interest in research on the impact of mobile phone addiction on young people is notorious [51], but its relationship with other important elements of education such as education in values has been minimally studied. This is evidenced by the scarce specific literature that exists today. One of the few studies is that conducted by Son and Huang [52], who analyze how mobile phone use influences the values of university students in a sample of 469 participants. Researchers have found significant differences in the values of equality and respect for parents and elders, and a negative correlation with students' values of social justice and cleanliness. Consequently, they conclude that dependence on mobile phones has a significant impact on the values of university students.

\subsection{Sustainable Education, Education in Values and the Use of the Mobile Phone}

Despite achievements in health and education, more than one billion people, many of them in conflict-affected areas, did not benefit from the Millennium Development Goals (MDGs). Therefore, Agenda 2030 has been proposed as a second principle so as to not leave anyone behind [53].

SDG 4, one of the 17 goals that make up the UN Agenda 2030 for Sustainable Development [54], aims to ensure access to quality education at all levels and to promote lifelong learning opportunities for all, and emphasizes special attention to the most disadvantaged social sectors, such as women in the most vulnerable communities. From the seven goals and the three implementation methods which comprise it, four of them are related to the objectives of our study: making sure that all children finish primary and secondary education, which must be fair and of quality, and creating the corresponding and effective learning results (4.1), that children have a quality early stage education, so that they are ready for primary education (4.2), guaranteeing fair access to quality training (4.3), and also focusing their attention on the importance of education for sustainability (4.7). As part of this last objective, we must remark on the importance of the students acquiring theoretical-practical knowledge required in order to promote sustainable development and adopt sustainable lifestyles.

Quality education goes beyond literacy rates, tuition fees, number of schooled children, student-teacher ratio or even the rate of students who have achieved reading, writing, and arithmetic competences. According to UNESCO [55], education must be based on the development of the three main commands: cognitive (knowledge and thinking tools to understand the SDGs), socioemotional (social skills to collaborate, negotiate, communicate, values, and self-reflection), and behavioral (action capability, active compromise with citizens). However, SDG 4 and its goals mainly focus on the first command, having identified some weaknesses in the training of attitudes and values [56].

A second existing problem is the persistence of gaps in the achievement of the SDG 4 goals [57]. Thus, the lowest rates of reading and mathematical competences are found in Sub-Saharan Africa, where $88 \%$ of the children in primary and secondary education do not have a command in reading and $84 \%$ of them do not have a command in mathematics. Likewise, there is a disparity in the participation of children in early stage education; in developed countries children are almost $100 \%$ present in early stage education, whereas in developing countries only $43 \%$ are present. Furthermore, the progress of children attending school, especially of girls, has come to a standstill in Central Asia, Northern Asia, West Asia, and Sub-Saharan Africa. In Central Asia, 27\% more girls than boys of schooling age do not attend primary school. Additionally, more than half the schools in Sub-Saharan Africa lack the basic elements for a quality education: qualified teachers, basic services of drinking water, the Internet, and computers. This situation worsens even more if we consider that the official reports about the Sustainable Development Goals, such as the UN Report [58], do not include progress in other main elements related to comprehensive training and sustainable development, such as socioemotional command, values, or ethics training.

Quality education (SDG 4), which is what in pedagogy is known as integral education $[59,60]$, is not only a right, but also the basis and strategy for social, economic, and environmental development with guarantees of current and future sustainability of all 
populations [61,62]. According to the terminology of the SDGs, this educational approach is known as Education for Sustainable Development (hereinafter ESD) [63]. It is characterized as such because it goes beyond the simple transmission of knowledge, as it promotes the acquisition of competences such as critical thinking, values that people need to have a successful life, to make informed decisions, and to take an active role both at the local and global level [59]. The purpose of ESD is for students to acquire the theoretical and practical knowledge necessary for the adoption of sustainable lifestyles, based on human rights, gender equality, solidarity, responsibility, the promotion of a culture of peace and non-violence, and the positive valuation of cultural diversity. In sum, ESD should be understood as an education that contributes to the construction of culture in and for sustainable development. As Irina Bokova, former Director General of UNESCO [55] points out: "A fundamental change is needed in the way we think about the role of education in global development because it has a catalytic effect on the well-being of individuals and the future of our planet. Now more than ever, education has a responsibility to keep up with the challenges and aspirations of the 21st century and to promote the right kinds of values and skills that will lead to sustainable and inclusive growth and a peaceful life together (p. 7)."

On the contrary, education that exclusively promotes economic growth leads to an increase in unsustainable consumption patterns [64]. Therefore, it is necessary to empower students so that they are able to reflect on their own actions, make conscious decisions and act responsibly for the sake of environmental integrity, economic viability, and a more sustainable and just society for all.

Societies in the world struggle to keep up with technological progress and globalization and in this process they face new challenges such as greater complexity and uncertainty, greater individualization, degradation of ecosystem services, greater vulnerability and exposure to natural and technological disasters, and expansion of economic and cultural uniformity. This reality requires a creative and autonomous action of "sustainable citizens" $[65,66]$, who are capable of knowing and understanding the complex world in which they live, and who can collaborate and develop actions for the sake of a positive change. To implement these actions, "sustainable citizens" need to display five types of competences that include cognitive elements but, especially, affective, volitional, and motivational elements (values, positive attitudes, and affective disposition): rule-based competence, collaboration, critical thinking, self-consciousness, and digital thinking [64]. These competences must include subject teaching [65] promoting experiential learning, initiative, the active participation of children and adolescents [66,67], and critical thinking [68,69]. They are necessary for all students of all ages and can be understood as key, transversal, and multifunctional competences [70-72] as they allow solving the obstacles that arise on a daily basis [73]. De Haan [74] and Rieckmann [75] argue that these competences are related to socioemotional learning objectives and are crucial to achieve sustainable development. Based on this, we propose specific values and attitudes for each of the five key competences (Table 1). 
Table 1. Key competences for sustainable development.

\begin{tabular}{|c|c|c|}
\hline Key Competency & Definition & Values \\
\hline Normative competency & $\begin{array}{l}\text { Skills to understand and reflect on the norms } \\
\text { and values that underlie our actions; and to } \\
\text { negotiate sustainability values, principles, } \\
\text { objectives, and goals in the context of conflicts } \\
\text { of interest and trade-offs, uncertain knowledge, } \\
\text { and contradictions. }\end{array}$ & $\begin{array}{l}\text { Justice, empathy, inclusion, solidarity, } \\
\text { equality, equity }\end{array}$ \\
\hline Collaboration competency & $\begin{array}{l}\text { Skills to learn from others; understanding and } \\
\text { respecting the needs, perspectives, and actions } \\
\text { of others (empathy); understanding, } \\
\text { identifying, and being sensitive to others } \\
\text { (empathic leadership); dealing with group } \\
\text { conflicts; and facilitating collaborative and } \\
\text { participatory problem solving. }\end{array}$ & $\begin{array}{l}\text { Open-mindedness, empathy, responsibility, } \\
\text { solidarity, affectivity, equality }\end{array}$ \\
\hline Critical thinking competency & $\begin{array}{l}\text { Ability to question norms, practices, and } \\
\text { opinions; reflecting on one's own values, } \\
\text { perceptions, and actions; and taking a stand on } \\
\text { the discourse of sustainability. }\end{array}$ & $\begin{array}{l}\text { Self-demand, reflection, respect, tolerance, } \\
\text { open-mindedness }\end{array}$ \\
\hline Self-awareness competency & $\begin{array}{c}\text { Ability to reflect on the role that each one has } \\
\text { in the local community and in (world) society; } \\
\text { to constantly evaluate and promote the actions } \\
\text { that one performs; and to deal with personal } \\
\text { feelings and desires. }\end{array}$ & Self-demand, trust, self-confidence, reflection \\
\hline Digital competency & $\begin{array}{l}\text { Ability to search, obtain, process, and } \\
\text { communicate information, and transform that } \\
\text { information into knowledge. It involves the } \\
\text { use of technologies in a safe, thoughtful, and } \\
\text { critical way. It also refers to problem solving } \\
\text { and the ability to evaluate, select, and } \\
\text { exchange information. }\end{array}$ & $\begin{array}{l}\text { Responsibility, inclusion, autonomy, critical } \\
\text { attitude, reflection }\end{array}$ \\
\hline
\end{tabular}

Based on this framework, this study aims to analyze and identify possible relationships between the values taught in school and addictions to mobile phones. Along these lines, the proposed hypotheses are the following:

Hypothesis 1 (H1). There is a negative and statistically significant relationship between the teaching of values in schools and addiction in children and adolescents.

Hypothesis 2 (H2). The teaching of values in schools is a predictor of the decrease and/or mitigation of mobile addiction.

\section{Materials and Methods}

\subsection{Data Design and Analysis}

The study is correlational and predictive. The "values taught at school" is the criterion variable that is related to the variable "addiction to mobile phones". The research is expected to reveal significant correlations between both variables. The software used for data analysis is SPSS. v. 26.

\subsection{Participants}

The technique used for data collection was convenience sampling [76]. Students from 69 schools in the province of Alicante (Spain) were invited to participate in the study. The selection criteria for the schools was that they had to offer studies in both educational stages: primary and secondary education. Of these, $17.3 \%$ were from 5 th grade and $22.3 \%$ 
from 6th grade of primary education; $13.2 \%$ of students were from 1st grade of secondary education, $18.1 \%$ were from 2 nd grade of secondary education and $29 \%$ were from 3rd grade of secondary education. In Spain, these educational stages are compulsory and free. Likewise, $76 \%$ of participants came from public schools, $22.2 \%$ from subsidized schools and $1.9 \%$ from private schools. In relation to gender, $61.3 \%$ were female compared to $38.7 \%$ male.

\subsection{Research Variables}

Independent variable: values taught at school.

Dependent variable: mobile addiction.

\subsection{Instrument}

The research on the relationship between education and mobile phones has focused on analyzing the educational benefits of this technological tool to enhance learning [77] and on examining the intrapersonal (e.g., attention deficit, depression) and interpersonal (social relations) problems generated by mobile dependence $[17,78]$. Consequently, the tools that have been developed to assess the behavioral problems related to mobile dependence, such as the Cellular Phone Dependence Questionnaire (CPDQ) [79], the Questionnaire of Experiences Related with Mobiles (CERM) [80], the Mobile Phone Dependence Inventory (MPDI) [81], or the Mobile Phone Problem Use Scale (MPPUS) [82] and to nomophobia, such as the Nomophobia Questionnaire (NMP-Q) [83] or the Mobile Phone Involvement Questionnaire (MPIQ) [84], have focused on the consequences of such problems (for example, the loss of communication and relationships, the negative influence on moods or deficient self-regulation). However, there are few studies on their relationship with values [11]. Therefore, in order to achieve the objectives of this study, and since no instrument linked to the specific subject matter of this study was found, an ad hoc instrument consisting of 86 items was designed for this purpose.

The questionnaire consisted of five sections. The first section had sociodemographic information on the participant: educational stage or level (5th and 6th years of primary education and 1st, 2nd, and 3rd years of compulsory secondary education), sex (male, female), type of educational center (public, subsidized, private), and place of residence. In the second section, 31 items were included referring to behaviors that occur in the classroom and /or in the educational center and that negatively affect the students and coexistence in the classroom, including mobile phone addiction. In the third section, made up of 24 items, we analyzed teachers' attitudes and willingness to promote a positive classroom atmosphere, and in the fourth section, made up of 10 items, we strictly analyzed critical thinking skills. Finally, the fifth section, which is the subject of this research, consisted of 21 items. In this case, students were asked what values and attitudes their teachers had taught them in the classroom. The following values, which are integrated in the Coeducation Master Plan of the Regional Department of Education, Research, Culture and Sports of the Valencian Community (Spain) were analyzed [85]: justice, empathy, affectivity, patience, responsibility, tolerance, equality, inclusion, solidarity, honesty, open-mindedness (openness to dialogue), being respectful and demanding respect, being impartial, being self-demanding, being able to set limits, being enthusiastic, having self-control, being balanced, being autonomous, developing positive self-esteem, and having self-confidence.

The items were evaluated with a Likert-type scale, with five answer options (from 1: never, to 5: always). After carrying out the reliability analysis, a Cronbach's alpha of 0.93 was obtained, which indicates a high correlation and homogeneity among the items. According to Vogt [86], a value of 0.7 or higher means that it is satisfactory for most cases, because it can be said that there is a great internal consistency between the items of the instrument. 


\subsection{Procedure}

Initially, the headmasters of the educational centers were contacted and an informative meeting was held with the research group. Once the corresponding permission for the application of the instrument was obtained, the tutoring teachers were contacted by e-mail in order to explain to them the purposes of the study. After approval, informed parental consent was sought. Afterwards, the questionnaire was sent to the students through the Google Forms platform. The questionnaire was voluntarily completed by the participants in their free time and outside of class hours. However, some teachers/tutors allowed them to answer the questionnaire during their assigned tutoring time (one hour per week). The data were collected between September 2019 and March 2020.

Once the information was collected, it was entered into an Excel database and quality control was carried out, having removed 8 questionnaires which had no answers.

\subsection{Measurements}

2.6.1. Correlation between the Values Taught at School and Mobile Addiction

The Spearman correlation analysis was carried out considering the nature of the variables under study (ordinal variables) and the normality checks. The correlation between the variables that measure the dimension "the values taught in schools" and the variable "mobile addiction" was analyzed through the nonparametric Spearman statistic.

\subsubsection{Linear Regression Analysis of the Values Taught in School and Addiction to} Mobile Phones

In order to better understand how the variables that determine the behavior of mobile addiction intervene, a linear regression analysis was performed. This allowed the identification of the predictive model and recognized the weight of the dimension "values taught in school" to explain the behavior of the variable "addiction to mobile phones".

\subsubsection{Logistic Regression Analysis of the Values Taught at School and Addiction to} Mobile Phones

Additionally to the linear regression analysis, and in order to know how the variables determine the behavior of mobile addiction, a logistic regression analysis was carried out. In this case, we performed the recoding of the dependent variable "mobile addiction" in a dichotomous or dummy variable. On the one hand, in one group we included the participants who answered "always" or "almost always", and, on the other hand, those who answered "never", "rarely", or "sometimes". This recoding was performed due to the divergences between this classification and the positive frequency of mobile addiction.

\section{Results}

This section explains the comparison of the scores of the values taught at school according to each education stage, the link between addiction and education stages, correlation, linear regression analysis, and polynomic logistic regression between the "values taught at school" and "mobile addiction", as well as the analysis according to the participants' educational stage.

\subsection{Comparison of the "Values Taught at School", According to the Educational Stage}

This analysis determines if the existing differences between the scores given to the factor "values taught at school" must be random or, if to the contrary, there is a behavioral pattern among the different groups. The verification of non-normality requires carrying out this analysis throughout Mann-Whitney's non-parametric technique, which replaces the comparison of means by medians.

Table 2 shows the statistics which measure the differences between mean ranges of each group and determine the existence of significant differences ( $p$-value $<0.001)$. As a result, it is possible to state that secondary education students score higher in the "values taught at school". 
Table 2. Mann-Whitney's U statistic value. Values taught at school, according to the academic stages.

\begin{tabular}{cc}
\hline & Values Taught at School \\
\hline Mann-Whitney's U & $200,276.000$ \\
Wilcoxon's W & $585,279.000$ \\
Z & -6.687 \\
(Bilateral) asymptotic sig. & 0.000 \\
\hline
\end{tabular}

\subsection{Link between Mobile Addiction and Educational Stages}

In order to determine if the dependent variable "mobile addiction" and the educational stages were linked, we carried out a contingency table with the observed frequencies and their associated Chi squared value. Table 3 presents the percentage differences in the frequency or relevance of mobile addiction according to the educational stages. The findings show that there is a clear link between both variables (Chi squared: 192.026, $p$-value $<0.001$ ) (Table 4). Thus, it can be affirmed that in each of the answer options for the dependent variable "mobile addiction" there are significant differences according to the educational stages. Therefore, the answer options "never", "rarely", and "sometimes" show a higher scope among primary education students compared to those from secondary education, meanwhile the answers "almost always" and "always" have higher percentages of "mobile addiction" among secondary education students compared to those from primary education.

Table 3. Contingency table. Percentages and frequency between mobile addiction and educational stages.

\begin{tabular}{|c|c|c|c|c|c|}
\hline & & & \multicolumn{2}{|c|}{ Educational Stage/Level } & \multirow{2}{*}{ Total } \\
\hline & & & Primary & Secondary & \\
\hline \multirow{10}{*}{ Mobile addiction } & \multirow[b]{2}{*}{ Never } & Count & 90 & 26 & 116 \\
\hline & & $\begin{array}{l}\% \text { in the corresponding } \\
\text { educational stage/level }\end{array}$ & $15.6 \%$ & $3.0 \%$ & $8.0 \%$ \\
\hline & \multirow[b]{2}{*}{ Rarely } & Count & 111 & 76 & 187 \\
\hline & & $\begin{array}{l}\% \text { in the corresponding } \\
\text { educational stage/level }\end{array}$ & $19.3 \%$ & $8.7 \%$ & $12.9 \%$ \\
\hline & \multirow[b]{2}{*}{ Sometimes } & Count & 145 & 143 & 288 \\
\hline & & $\begin{array}{l}\% \text { in the corresponding } \\
\text { educational stage/level }\end{array}$ & $25.2 \%$ & $16.3 \%$ & $19.8 \%$ \\
\hline & \multirow[b]{2}{*}{ Almost always } & Count & 148 & 294 & 442 \\
\hline & & $\begin{array}{l}\% \text { in the corresponding } \\
\text { educational stage/level }\end{array}$ & $25.7 \%$ & $33.5 \%$ & $30.4 \%$ \\
\hline & \multirow[b]{2}{*}{ Always } & Count & 82 & 338 & 420 \\
\hline & & $\begin{array}{l}\% \text { in the corresponding } \\
\text { educational stage/level }\end{array}$ & $14.2 \%$ & $38.5 \%$ & $28.9 \%$ \\
\hline \multirow{2}{*}{\multicolumn{2}{|c|}{ Total }} & Count & 576 & 877 & 1453 \\
\hline & & $\begin{array}{l}\% \text { in the corresponding } \\
\text { educational stage/level }\end{array}$ & $100.0 \%$ & $100.0 \%$ & $100.0 \%$ \\
\hline
\end{tabular}


Table 4. Chi squared to measure the link between mobile addiction and the educational stages.

\begin{tabular}{cccc}
\hline \multicolumn{4}{c}{ Chi-Squared Tests } \\
\hline Value & df & $\begin{array}{c}\text { (Bilateral) } \\
\text { Asymptotic Significance }\end{array}$ \\
\hline Pearson's Chi-squared & $192.026^{\text {a }}$ & 4 & 0.000 \\
Likelihood ratio & 197.814 & 4 & 0.000 \\
Linear by linear association & 190.516 & 1 & 0.000 \\
N of valid cases & 1453 & & \\
\hline${ }^{a}$ 0 squares $(0.0 \%)$ a count lower to 5 expected. Minimum count expected 45.98.
\end{tabular}

\subsection{Estimation of "Mobile Addiction" Based on the "Values Taught at School"}

When carrying out the binary logistic regression in order to determine if the variable school values predict the behavior of the dependent variable "mobile addiction", it was seen that the model is significant ( $\mathrm{b}:-0.184, p$-value $<0.05$ ) and the variable "values taught at school" has a significant and negative coefficient. This means that the higher the score in "values taught at school", the lower the score in "mobile addiction" (Table 5).

Table 5. Logistic regression model of "mobile addiction" through the factor "values taught at school".

\begin{tabular}{cccccccc}
\hline \multicolumn{8}{c}{ Equation Variables } \\
\hline & B & Standard Error & Wald & gl & Sig. & Exp(B) \\
\hline Step 1 & $\begin{array}{c}\text { Values taught at } \\
\text { school (average items: } \\
57+\ldots+77) \\
\text { Constant }\end{array}$ & -0.184 & 0.073 & 6.373 & 1 & 0.012 & 0.832 \\
\hline Variables specified in step 1: values taught at school (Average items: $57+\ldots+77)$. & & & & \\
& 1.101 & 0.292 & 14.179 & 1 & 0.000 & 3.008 \\
\hline
\end{tabular}

\subsection{Estimation of the Model According to the Educational Stage}

The model is conditioned when using the variable which classifies the students according to their corresponding educational stage, therefore it was necessary to find out if the students' educational level has an influence on "mobile addiction". For this purpose, the model was replicated including the "educational stage": primary education and secondary education. In this case, the strongest variable in the academic stage obtained a positive and significant coefficient ( $\mathrm{b}: 1.347, p$-value $<0.01$ ), which means that secondary education students are more likely to have mobile addiction compared to those from primary education (Table 6).

Table 6. Logistic regression model of "mobile addiction" through the factor "values taught at school" and the academic stages.

\begin{tabular}{ccccccccc}
\hline & Equation Variables & & & \\
\hline & & B & Standard Error & Wald & gl & Sig. & Exp(B) \\
\hline \multirow{2}{*}{ Step 1 } & $\begin{array}{c}\text { Secondary education stage } \\
\text { "Values taught at school" }\end{array}$ & 1.347 & 0.115 & 136.620 & 1 & 0.000 & 3.846 \\
& (Average items: $57+\ldots+77)$ & -0.035 & 0.077 & 0.205 & 1 & 0.651 & 0.966 \\
& Constant & -0.266 & 0.326 & 0.662 & 1 & 0.416 & 0.767 \\
\hline
\end{tabular}

Specified variables in Step 1: secondary education, values taught at school (average items: $57+\ldots+77$ ).

\subsection{Correlation between the Values Taught at School and Mobile Addiction}

The items of the component that make up the predictive or explanatory variable ("values taught at school") correlate positively and significantly among them, but what is interesting is to observe in the study is how these items correlate with the item that describes mobile addiction. In this sense, it is observed that the items that make up the independent variable correlate indirectly with the items that define the criterion variable; therefore, the higher the value in the statements about the values taught at school, the less 
addiction to the mobile phone. These correlations are significant in 10 of the 21 items that make up the dimension "values taught in schools" (Table 7). Solidarity is the value that shows the highest correlation $(-0.109)$, which implies that the most supportive individuals have less addiction to mobile phones, followed by those who have acquired the value of inclusion $(-0.74)$, justice $(-0.72)$, being enthusiastic $(-0.72)$, patience $(-0.69)$, being impartial $(-0.61)$, open-mindedness $(-0.60)$, honesty $(-0.59)$, and having balance $(-0.58)$.

Table 7. Correlation between the items that make up the dimension that shapes "values taught at school" and "mobile addiction".

\begin{tabular}{cc}
\hline Items That Make Up the Dimension "Values Taught at Schools" & Mobile Addiction \\
\hline Justice & $-0.072^{* *}$ \\
Empathy & -0.035 \\
Affectivity & -0.051 \\
Patience & $-0.069^{* *}$ \\
Responsibility & -0.019 \\
Tolerance & $-0.060^{*}$ \\
Equality & -0.047 \\
Inclusion & $-0.074^{* *}$ \\
Solidarity & $-0.109 *$ \\
Honesty & $-0.059^{*}$ \\
Openness-mindedness & $-0.060^{*}$ \\
Being respectful and demanding respect & 0.003 \\
Being impartial & $-0.061^{*}$ \\
Being self-demanding & -0.012 \\
Being able to set limits & -0.024 \\
Being enthusiastic & $-0.072^{* *}$ \\
Having self-control & -0.035 \\
Having balance & $-0.058^{*}$ \\
Being autonomous & -0.015 \\
Develop positive self-esteem & -0.040 \\
Having self-confidence & -0.026 \\
\hline
\end{tabular}

${ }^{*} p<0.05,{ }^{* *} p<0.01$.

In order to visually establish how the point cloud is drawn between the dimension "values at schools" and "mobile addiction", Figure 1 illustrates the linear correlation between both variables, categorized according to the educational stage (primary education and secondary education).

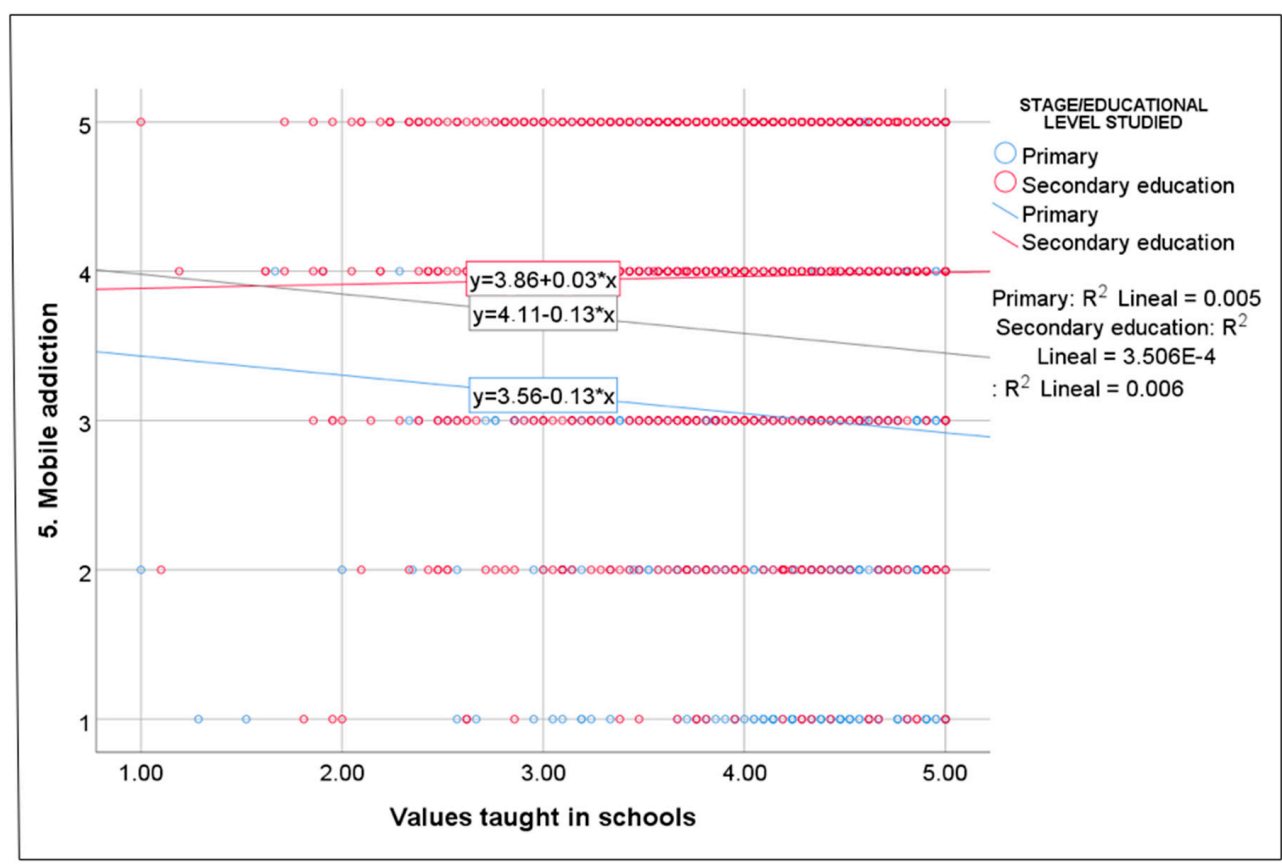

Figure 1. Scatter plot. Values taught at schools and mobile addiction (average items: $57+\ldots+77$ ). 
In the graph above we can see the visual representation of the number of cases which reflect those scores given to the factor "values taught at school" and "mobile addiction" in primary education and secondary education. The point cloud does not seem to betray the linear correlation clearly and an example of this are the low correlation coefficients. However, if we segment by school group, it is observed how the line that optimally represents the cut-off point in the point cloud belongs to the primary education students. Its slope is steeper and in the opposite direction. The implication for primary education students is that, the higher the values taught in the school, the less addiction they have to mobile phones. On the other hand, in the case of secondary education students, the slope is not so significant.

\subsection{Linear Regression Analysis of "Values Taught at School" and "Mobile Addiction"}

In order to better understand how the variables that determine "mobile addiction" intervene, to identify the predictive model and recognize the weight of the dimension "values taught at school", and to explain the behavior of the variable "mobile addiction", a linear regression analysis was performed (Table 8).

Table 8. Predictive regression model of "mobile addiction" by means of the factor "values taught at school".

\begin{tabular}{cccc}
\hline & $\boldsymbol{b}$ & $\boldsymbol{T}$ & Model \\
\hline $\begin{array}{c}\text { Model } \\
\text { Taught values }\end{array}$ & -0.007 & $-3.291^{* *}$ & $\mathrm{R}^{2}=0.007 \mathrm{~F}(1.1435)=10.829^{* *}$ \\
${ }^{* *} p<0.01$. & & \\
\hline
\end{tabular}

It is observed that the value assigned to the factor "values taught at school" is significant. This leads us to affirm that this dimension has a negative influence on "mobile addiction". The variable explains $0.7 \%$ of the variance of the "mobile addiction" factor, which is statistically significant. The low proportion of explained variance of the dependent variable is due to the fact that the point cloud drawn by the model (Figure 1) does not represent the ideal slope to cross a straight line between its points, while in other scattered data points, the predictions reflect some uncertainty.

\subsection{The Academic Stage, Values, and Mobile Addiction}

The model is conditioned when the variable that classifies students according to the educational stage in which they are intervenes, so it was necessary to inquire whether the educational level of the student influences the "mobile addiction". For this, the model was replicated including the "educational stage": primary education and secondary education (Table 9).

Table 9. Predictive regression model of "mobile addiction" by means of the factor "values taught at school".

\begin{tabular}{cccc}
\hline & $\boldsymbol{b}$ & $\boldsymbol{T}$ & Model \\
\hline Model & & & $\mathrm{R}^{2}=0.133 \mathrm{~F}(2,1434)=109.84^{* *}$ \\
Taught values & -0.002 & -0.973 & \\
Primary & -0.919 & $-14.398^{* *}$ & \\
Education & & & \\
${ }^{* *} p<0.01$. & &
\end{tabular}

As soon as the educational stage intervenes, the dimension "values taught in school" is no longer significant in the predictive model. The variability of the model gains in goodness of fit, since it goes from $0.7 \%$ when only the dimension "taught values" intervenes, to $13.3 \%$ when the educational stage taken by the student is included. This shows that the academic stage significantly influences the model. Therefore, students in primary education are more 
likely to have low scores in "mobile addiction" compared to secondary education students. In other words, the model obtained can be interpreted as keeping the dimension "values taught in school" constant, as primary education students give a lower score to "mobile addiction" than secondary education students.

\section{Discussion}

We live in a diverse and ever-changing world, where poverty and wealth, natural disasters, hunger, and inequality coexist alongside the rapid development of technology, social media, and information. In this context, ESD, whose ally is technology, is essential to achieve the Sustainable Development Goals [87]. Education must not only provide students with knowledge, but also skills for personal development, for work in learning communities, and for responsible citizenship [88].

\section{Correlation between the Values Taught at School and Mobile Addiction}

The frequent use of mobile phones by children and adolescents worldwide has generated positive but also negative results on their academic performance [17,37-39], on their mental and physical health, and, in general, on their well-being [44,46-48].

Regarding the negative results, $39.5 \%$ of Spanish adolescents have problems of mobile dependence [50], such as compulsive behaviors [26,27] and lack of control [28-33], which negatively influences their academic performance [37-39], and even on their physical and mental health $[47,48]$. Given the magnitude and importance of these problems, schools must compromise to develop an education oriented to the responsible use of mobiles and technology. In this sense, the objective of this study was to analyze and identify the possible relationships between the values taught at school and mobile addiction.

The main findings show that there is a significant negative correlation between the "values taught at schools" and "mobile addiction" (-0.091) (Hypothesis 1), which was confirmed by the logistic regression analysis (b: $-0.184, p$-value $<0.05)$. This means that the more these values are taught at school, the less the mobile addiction.

The teaching and learning of values at school lines up with the fundamentals of quality education (SDG 4) from the Agenda 2030, which recommends that, beyond the cognitive domain, the socioemotional and behavioral domains are developed in students, focusing on values, ethics, and responsible citizenship [56,58].

Likewise, from the data analysis, it is deducted that teaching values at educational centers is a predictor of the decrease and/or mitigation of mobile addiction (Hypothesis 2), since, as we have seen in the analysis of the results, the higher the value in the statements about the values taught at schools, the lower the mobile addiction. This correlation is especially significant with respect to "solidarity" (-0.109), which means that the most supportive students have less mobile addiction, followed by those who have acquired social values such as inclusion, justice, and personal values such as enthusiasm, patience, impartiality, open-mindedness, honesty, and balance. These findings are consistent with the study by Son and Huang [52], who analyzed how the use of mobile phones has an influence on the values of university students and concluded that dependence on mobile phones has a significant impact on the values of university students, especially on the values of equality, respect for parents and the elderly, justice, and cleanliness.

The linear regression analysis also confirms the first hypothesis and shows that the values taught at school have a negative influence on "mobile addiction". This factor analysis reflects $0.7 \%$ of the variance of "mobile addiction", which is statistically significant. In this sense, it is necessary to state that, although such variance does not have a considerable importance, it shows clear evidence of the behavior among variables, which has been noted. Likewise, we must conclude that there is a direct relationship between "mobile addiction" and the educational stages (Chi squared 192,026, $p$-value < 0.001), and there are differences according to the participants' corresponding educational stage. Therefore, there is higher mobile addiction in the secondary education students compared to those from primary education, whose mobile addiction scores are lower. These findings confirm 
the conclusions by Ruiz et al. [49] and Aranda et al. [51], who endorse the trend that adolescence is the stage most prone to this type of addiction. For adolescents, mobile phones are useful and symbolic devices which allow them to achieve the long yearned autonomy, obtain peer recognition, communicate, and also show their identity [89]. In view of this, schools must face the challenges that technological progress offers and take part in order to stop the vulnerability and exposure to danger which comes with the excessive use of mobile phones by children and adolescents. In order to do so, all the parts involved in education are important, especially families and schools. This study brings to light, on the one hand, the need to have school preventive programs focusing on the development of values and positive habits and, on the other hand, to adopt intervention measures with and educational and pedagogic approach, and not only a punitive and penalizing approach, since it could have interesting results in the responsible use of mobile phones. These programs must be integrated in the tutoring plan and the coexistence plan at schools, so that they are mainstream actions which involve all members of the educational community and are connected to the subjects of the school curriculum [90]. The key competences for sustainable development (normative, collaborative, critical thinking, self-consciousness), among which digital competence is included, will not be achieved if they are not integrated with values.

\section{Conclusions}

Advancing on the path of sustainable development requires a deep transformation of education. In order to create a more sustainable world, people must be true agents of change and for this they need knowledge, skills, and values that empower them [91]. Next we will explain the main conclusions of this study:

1. The values identified in this study are necessary both for the responsible use of ICT and for sustainable development, therefore it is recommended that they be integrated into the education of students of all ages, but especially at an early age.

2. From the relationship found between values and mobile addiction, it is possible to suspect that education in values, focused on solidarity, inclusion, justice, enthusiasm, patience, impartiality, open-mindedness, honesty, and balance, may mitigate mobile addiction or at least promote a responsible use of such technology. In any case, it is necessary to carry out more studies, mainly linear, in order to confirm this premise. However, what is clear is that in education in values it is key to have the participation of all members of the educational community, especially teachers and relatives [49].

3. SDG 4 defends that quality education is not only a right, but the strategy for social, economic, and environmental development, with guarantees of sustainability. Therefore, schools must train sustainable citizens, who participate, responsibly and constructively, in their environment and in the world [92,93]. Hence, education must develop a greater awareness of reality and the need for change, to act responsibly for the sake of environmental integrity, economic viability, and a just society for all, both at present and in the future $[53,61,94]$.

\section{Limitations and Prospects}

Finally, we must point out the study limitations. First, the results cannot be generalized, since the sample is not sufficiently representative of each age group. Likewise, in the research there was a lack of evidence to support the effect of mobile phone use with respect to other demographic variables, such as gender, ethnicity, or social class. Furthermore, as a prospect, it would be interesting to analyze other external factors that could be affecting mobile addiction, such as social cohesion and confinement motivated by COVID-19. Given the reality of excessive use of mobile phones, it is necessary to continue investigating the new meanings that children and adolescents give to communication and entertainment through this technology. 
Author Contributions: Conceptualization, G.M.-M. and D.G.-M.; methodology, G.M.-M., D.G.-M. and J.-F.Á.-H.; software, J.-F.Á.-H. and D.G.-M.; validation, G.M.-M., D.G.-M., and J.-F.Á.-H.; formal analysis, G.M.-M. and D.G.-M.; investigation, G.M.-M., D.G.-M., and J.-F.Á.-H.; resources, G.M.-M. and D.G.-M.; data curation, D.G.-M. and J.-F.Á.-H.; writing-original draft preparation, G.M.-M. and D.G.-M.; writing-review and editing, G.M.-M., D.G.-M., and J.-F.Á.-H.; visualization, J.-F.Á.-H.; supervision, G.M.-M.; project administration, D.G.-M. and J.-F.Á.-H. All authors have read and agreed to the published version of the manuscript.

Funding: This research was financed by the University of Alicante and the Generalitat Valenciana (Spain) within the framework of the Interdisciplinary Research Network on Curriculum Design to integrate SDGs into AU curriculum subjects (RES. CUD-05-2019).

Institutional Review Board Statement: Not applicable.

Informed Consent Statement: Not applicable.

Data Availability Statement: Not applicable.

Acknowledgments: We are grateful for the participation of the school directors, teachers and students of the centers where the study was carried out.

Conflicts of Interest: The authors declare no conflict of interest.

\section{References}

1. Turow, J.; Couldry, N. Media as data extraction: Towards a new map of a transformed communications field. J. Commun. 2018, 68, 415-423. [CrossRef]

2. Masip, P.; Guallar, J.; Suau, J.; Ruiz-Caballero, C.; Peralta, M. News and social networks: Audiencia behavior. Prof. Inf. 2015, 24, 364-370. [CrossRef]

3. Buckingham, D. Más Allá de la Tecnología. Aprendizaje Infantil en la Era de la Cultura Digital; Ediciones Manantial: Buenos Aires, Argentina, 2008.

4. Jenkins, H.; Carpentier, N. Theorizing participatory intensities: A conversation about participation and politics. Convergence 2013, 19, 265-286. [CrossRef]

5. Rivotella, P.C. Digital Literacy: Tools and Methodologies for Information Society; IRM Press: Hershey, PA, USA, 2008.

6. Buckingham, D. Epilogue: Rethinking digital literacy: Media education in the age of digital capitalism. Dig. Educ. Rev. 2020, 37, 230-239. [CrossRef]

7. Rivotella, P.C. Media Education: Idea, Método, Ricerca; LaScuola: Brescia, Italy, 2017.

8. Tirocchi, S. Sociologie della Media Education; Franco Angeli: Milano, Italy, 2013.

9. Nhamo, G.; Nhemachena, C.; Nhamo, S. Using ICT indicators to measure readiness of countries to implement Industry 4.0 and the SDGs. Environ. Econ. Policy Stud. 2020, 22, 315-337. [CrossRef]

10. Malley, C.O.; Vavoula, G.; Glew, J.P.; Taylor, J.; Sharples, M. Guidelines for Learning/Teaching/Tutoring in a Mobile Environment. Report. 2005. Available online: https://acortar.link/SfwLg (accessed on 12 October 2020).

11. Salcines-Talledo, I.; González-Fernández, N.; Briones, E. The Smartphone as a pedagogic tool. Student profiles as related to its use and knowledge. NAER 2020, 9, 91-109. [CrossRef]

12. Crompton, H.; Burke, D.; Gregory, K.H. The use of mobile learning in PK-12 education: A systematic review. Comput. Educ. 2017, 110, 51-63. [CrossRef]

13. Mojarro, A.; Duarte, A.M.; Guzmán, M.; Aguaded, I. Mobile learning in university contexts based on the unified theory of acceptance and use of technology (UTAUT). NAER 2019, 8, 7-17. [CrossRef]

14. Vázquez-Cano, E.; Sevillano-García, M.L. Ubiquitous educational use of mobile digital devices. A general and comparative study in Spanish and Latin America higher education. NAER 2018, 113-123. [CrossRef]

15. Daher, W. Building mathematical knowledge in an authentic mobile phone environment. Australas. J. Educ. Technol. 2010, 26, 85-104. [CrossRef]

16. Miller, H.B.; Cuevas, J.A. Mobile Learning and its effects on academic achievement and student motivation in middle grades students. Int. J. Scholarsh. Technol. Learn. 2017, 1, 91-110.

17. Gi, D.; Park, Y.; Kyung, M.; Park, J. Mobile phone dependency and its impacts on adolescents' social and academic behaviors. Comput. Hum. Behav. 2016, 63, 282-292. [CrossRef]

18. Asante, K.O.; Nyako, J. The physical and behavioural consequences of Facebook use among university students. Mediterr. J. Soc. Sci. 2014, 5, 774-781. [CrossRef]

19. Kim, E.; Cho, I.; Kim, E.J. Structural equation model of smartphone addiction based on adult attachment theory: Mediating effects of loneliness and depression. Asian Nurs. Res. 2017, 11, 92-97. [CrossRef]

20. Li, J.; Lepp, A.; Barkley, J.E. Locus of control and cell phone use: Implications for sleep quality, academic performance, and subjective well-being. Comput. Hum. Behav. 2015, 52, 450-457. [CrossRef] 
21. Enez, A.; Kose, S.; Noyan, C.O.; Nurmedov, S.; Yılmaz, O.; Dilbaz, N. Smartphone addiction and its relationship with social anxiety and loneliness. Behav. Inf. Technol. 2016, 35, 520-525. [CrossRef]

22. Epdata. Los Menores y las Nuevas Tecnologías, en Datos y Gráficos. Available online: https://acortar.link/ikPRr (accessed on 12 September 2020).

23. Masip, M.; Balagué, I. El Uso del Teléfono Móvil en España; Desconecta, Instituto Psicológico: Barcelona, Spain, 2015.

24. Jackson, L.A.; Von Eye, A.; Fitzgerald, H.E.; Witt, E.A.; Zhao, Y. Internet use, videogame playing and cell phone use as predictors of children's body mass index (BMI), body weight, academic performance, and social and overall self-esteem. Comput. Hum. Behav. 2011, 27, 599-604. [CrossRef]

25. Muñoz-Rivas, M.; Agustín, S. La adicción al teléfono móvil. Psicol. Conduct. 2005, 13, 481-493.

26. Pedrero-Pérez, E.J.; Morales-Alonso, S.; Ruiz-Sánchez de León, J.M. Obsession and compulsion in mobile phone use/abuse: OCDUS-ICT. Adicciones 2020, 1320. [CrossRef]

27. Roberts, J.; Pullig, C.; Manollis, C. I need my smartphone: A hierarchical model of personality and cell-phone addiction. Personal. Individ. Differ. 2015, 79, 13-19. [CrossRef]

28. Domoff, S.E.; Foley, R.P.; Ferkel, R. Addictive phone use and academic performance in adolescents. Hum. Behav. Emerg. Technol. 2019, 2, 33-38. [CrossRef]

29. Holden, C. Behavioral addictions: Do they exist? Science 2001, 294, 980-982. [CrossRef] [PubMed]

30. LaRose, R.; Lin, C.A.; Eastin, M.S. Unregulated Internet usage: Addiction, habit, or deficient self-regulation. Media Psychol. 2003, 5, 225-253. [CrossRef]

31. Lemon, J. Can we call behaviours addictive? Clin. Psychol. 2002, 3, 44-49. [CrossRef]

32. Martínez-Sánchez, I.; Goig-Martínez, R.M.; Álvarez-Rodríguez, J.; Fernández-Cruz, M. Factors contributing to mobile phone dependence amongst young people-Educational implications. Sustainability 2020, 12, 2554. [CrossRef]

33. Yu, S.; Sussman, S. Does smartphone addiction fall on a continuum of addictive behaviors? Int. J. Environ. Res. Public Health 2020, 17, 422. [CrossRef] [PubMed]

34. Goswami, V.; Singh, D.R. Impact of mobile phone addiction on adolescent's life: A literature review. Int. J. Home Sci. 2016, 2, 69-74.

35. Chen, Q.; Yan, Z. Does multitasking with mobile phones affect learning? A review. Comput. Hum. Behav. 2016, 54, 34-42. [CrossRef]

36. Rashid, T.; Asghar, H.M. Technology use, self-directed learning, student engagement and academic performance: Examining the interrelations. Comput. Hum. Behav. 2016, 63, 604-612. [CrossRef]

37. Hong, W.; Liu, R.D.; Ding, Y.; Zhen, R.; Jiang, R.; Fu, X. Autonomy need dissatisfaction in daily life and problematic mobile phone use: The mediating roles of boredom proneness and mobile phone gaming. Int. J. Environ. Res. Public Health 2020, 17, 5305. [CrossRef]

38. Jun, S. Longitudinal influences of depressive moods on problematic mobile phone use and negative school outcomes among Korean adolescents. Sch. Psychol. Int. 2019, 40, 294-308. [CrossRef]

39. Veysel, A.; Ari, E. A marketing approach to a psychological problem: Problematic smartphone use on adolescents. Int. J. Environ. Res. Public Health 2020, 17, 2471. [CrossRef]

40. Gupta, N.; Garg, S.; Arora, K. Pattern of mobile phone usage and its effects on psychological health, sleep, and academic performance in students of a medical university. Natl. J. Physiol. Pharm. Pharmacol. 2016, 6, 132-139. [CrossRef]

41. Lin, T.T.; Chiang, Y.H. Investigating predictors of smartphone dependency symptoms and effects on academic performance, improper phone use and perceived sociability. Int. J. Mob. Commun. 2017, 15, 655-676. [CrossRef]

42. Longnecker, E.M. The Relationship between Smartphone Use, Symptoms of Depression, Symptoms of Anxiety, and Academic Performance in College Students; Iowa State University: Ames, IA, USA, 2017.

43. Raheem, R.; Salman, F.; Alam, S.; Streimikiene, D.; Hussain, R.; Hussain, P. Smartphone use and academic performance of university students: A mediation and moderation analysis. Sustainability 2020, 12, 439. [CrossRef]

44. Samaha, M.; Hawi, N.S. Relationships among smartphone addiction, stress, academic performance, and satisfaction with life. Comput. Hum. Behav. 2016, 57, 321-325. [CrossRef]

45. Beland, L.P.; Murphy, R. Ill communication: Technology, distraction \& student performance. Labour Econ. 2016, 41, 61-76. [CrossRef]

46. Bhatt, N.; Muninarayanappa, N.V.; Nageshwar, V. A study to assess the mobile phone dependence level and sleep quality among students of selected colleges of Moradabad. Indian J. Public Health Res. Dev. 2017, 8, 41-45. [CrossRef]

47. Han, L.; Geng, J.; Jou, M.; Gao, F.; Yang, H. Relationship between shyness and mobile phone addiction in Chinese young adults: Mediating roles of self-control and attachment anxiety. Comput. Hum. Behav. 2017, 76, 363-371. [CrossRef]

48. Lee, S.Y.; Lee, H.K.; Choi, J.S.; Bang, S.Y.; Park, M.H.; Jung, K.I.; Kweon, Y.S. The matthew effect in recovery from smartphone addiction in a 6-month longitudinal study of children and adolescents. Int. J. Environ Res. Public Health 2020, 17, 4751. [CrossRef]

49. Ruiz, P.J.; Sánchez, R.J.; Trujillo, T.J. Utilización de internet y dependencia a teléfonos móviles en adolescentes. Rev. Latin. Cienc. Soc. Niñ. Juv. 2016, 14, 1357-1369. [CrossRef]

50. De la Villa-Moral, M.; Suárez, C. Factores de riesgo en el uso problemático de internet y del teléfono móvil en adolescentes españoles. Rev. Iberoam. Psi. Sal. 2016, 7, 69-78. [CrossRef]

51. Aranda, M.; Fuentes, V.; García-Domingo, M. "No sin mi Smartphone": Elaboración y validación de la Escala de Dependencia y Adicción al Smartphone (EDAS). Terap. Psicol. 2017, 35, 35-45. [CrossRef] 
52. Song, M.; Huang, H. An empirical study on the effect of mobile phone dependence on college students' values. Chin. J. Health Psychol. 2017, 5, 23.

53. United Nations. Universal Values. Principle Two: Leave No One Behind. Available online: https://acortar.link/rfsof (accessed on 9 July 2020).

54. United Nations. Transforming Our World: The 2030 Agenda for Sustainable Development, United Nations. Available online: https: / / acortar.link/jjCyt (accessed on 10 March 2020).

55. UNESCO. Education for Sustainable Development Goals. Learning Objectives; UNESCO: Paris, Italy, 2017.

56. Education International. Guide to Indicators for SDG 4 Quality Education. Education International Toolkit. Available online: https://download.ei-ie.org/Docs/WebDepot/2017_SDGs_Toolkit_eng_v1.1.pdf (accessed on 10 January 2021).

57. Boeren, E. Understanding Sustainable Development Goal (SDG) 4 on "quality education" from micro, meso and macro perspectives. Int. Rev. Educ. 2019, 65, 277-294. [CrossRef]

58. United Nations. The Sustainable Development Goals Report. Available online: https://acortar.link/4Iskj (accessed on 7 November 2020).

59. Altarejos, F.; Naval, C. Filosofía de la Educación, 3rd ed.; EUNSA: Pamplona, Spain, 2011.

60. UN. Declaración y el Programa de Acción de Viena Aprobados por la Conferencia Mundial de Derechos Humanos el 25 de Junio de 1993. Available online: https:/ / acortar.link/j7WD2 (accessed on 10 March 2020).

61. UNESCO. Roadmap for Implementing the Global Action Programme on Education for Sustainable Development; United Nations Educational, Scientific and Cultural Organisation: Paris, Italy, 2014.

62. UNESCO. Documento de Posición Sobre la Educación Después de 2015. Acc. Pedag. 2015, 24, $134-147$.

63. Leicht, A.; Heiss, J.; Byun, W.J. Issues and Trends in Education for Sustainable Development; UNESCO Publishing: Paris, Italy, 2018; Volume 5.

64. Council of the European Union. Recomendación del Consejo, de 22 de Mayo de 2018, Relativa a Las Competencias Clave Para el Aprendizaje Permanente. In Diario Oficial de la Unión Europea; C189/1-C189-13; Official Journal of the European Union: Brussels, Belgium, 2018; Available online: https: / / acortar.link/ndRQM (accessed on 3 June 2020).

65. Lambrechts, W.; Van Petegem, P. The interrelations between competences for sustainable development and research competences. Int. J. Sustain. Higher Educ. 2016, 17, 776-795. [CrossRef]

66. Kolb, D. Experiential Learning: Experience as the Source of Learning and Development; Prentice Hall: Upper Saddle River, NJ, USA, 1984.

67. Moon, J.A. A Handbook of Reflective and Experiential Learning: Theory and Practice; Routledge Falmer: London, UK, 2004.

68. Baron, J.; Gürçay, B.; Metz, S.E. Reflection, intuition, and actively open-minded thinking. In Individual Differences in Judgment and Decision Making from a Developmental Context; Toplak, M., Weller, J., Eds.; Routledge: New York, NY, USA, 2017 ; pp. 107-126.

69. Facione, P. Critical Thinking: A Statement of Expert Consensus for Purposes of Educational Assessment and Instruction; The California Academic Press: Millbrea, CA, USA, 1990.

70. Rychen, D.S. Competencias clave: Abordar desafíos importantes en vida Rychen. In Competencias Clave Para una Vida Exitosa y una Sociedad Sana; Rychen, D.S., Salganik, L.H., Eds.; Hogrefe y Huber: Cambridge, UK, 2003; pp. 63-107.

71. Wiek, A.; Withycombe, L.; Redman, C.L. Key competencies in sustainability: A reference framework for academic program development. Sustain. Sci. 2011, 6, 203-218. [CrossRef]

72. Weinert, F.E. Concept of competence: A conceptual clarification. In Defining and Selecting Key Competencies; Rychen, D.S., Salganik, L.H., Eds.; Hogrefe: Göttingen, Germany, 2001; pp. 45-65.

73. Cabero-Almenara, J.; Romero-Tena, R.; Palacios-Rodríguez, A. Evaluation of teacher digital competence frameworks through expert jument: The use of the expert competence coefficient. NAER 2020, 9, 275-293. [CrossRef]

74. De Haan, G. El desarrollo de las competencias relacionadas a la EDS en los marcos institucionales de apoyo. Int. Rev. Educ. 2010, 56, 315-328. [CrossRef]

75. Rieckmann, M. Educación superior orientada hacia el futuro: ¿Qué competencias clave se deberían fomentar mediante la enseñanza y la educación universitaria? Futures 2012, 44, 127-135. [CrossRef]

76. Losada, J.L.; López-Feal, R. Métodos de Investigación en Ciencias Humanas y Sociales; Thomson-Paraninfo: Madrid, Spain, 2003.

77. Heflin, H.; Shewmaker, J.; Nguyen, J. Impact of mobile technology on student attitudes, engagement, and learning. Comput. Educ. 2017, 107, 91-99. [CrossRef]

78. Lee, Y.K.; Chang, C.T.; Lin, Y.; Cheng, Z.H. The dark side of smartphone usage: Psychological traits, compulsive behavior and technostress. Comput. Hum. Behav. 2014, 31, 373-383. [CrossRef]

79. Toda, M.; Monden, K.; Kubo, K.; Morimoto, K. Cellular phone dependence tendency of female university students. Jpn. J. Hyg. 2004, 59, 383-386. [CrossRef] [PubMed]

80. Beranuy, M.; Oberst, U.; Carbonell, X.; Chamarro, A. Problematic Internet and mobile phone use and clinical symptoms in college students: The role of emotional intelligence. Comput. Hum. Behav. 2009, 25, 1182-1187. [CrossRef]

81. Xu, H.; Wu, X.; Lan, Y.; Chen, Y. Development of Mobile Phone Dependence Inventory for college students. Chin. J. Clin. Psychol. 2008, 16, 26-27.

82. López, O.; Honrubia-Serrano, M.L.; Freixa-Blanxart, M. Adaptación española del "Mobile Phone Problem Use Scale" para población adolescente. Adicciones 2012, 24, 123-130. [CrossRef]

83. Yildirim, C. Exploring the Dimensions of Nomophobia: Developing and Validating a Questionnaire Using Mixed Methods Research; University of Iowa: Iowa City, IA, USA, 2014. 
84. Argumosa-Villar, L.; Boada-Grau, J.; Vigil-Colet, A. Exploratory investigation of theoretical predictors of nomophobia using the Mobile Phone Involvement Questionnaire (MPIQ). J. Adolesc. 2017, 56, 127-135. [CrossRef] [PubMed]

85. Generalitat Valenciana. Coeducation Master Plan. Consellería de Educación, Investigación, Cultura y Deporte. 2018. Available online: https: / / acortar.link/Xe5p3 (accessed on 22 June 2020).

86. Vogt, P. Quantitative Research Methods for Professionals; Pearson/Allyn and Bacon: Boston, MA, USA, 2007.

87. Wu, J.; Guo, S.; Huang, H.; Liu, W.; Xiang, Y. Information and communications technologies for sustainable development goals: State-of-the-art, needs and perspectives. IEEE Commun. Surv. Tutor. 2018, 20, 2389-2406. [CrossRef]

88. Arizmendi, M.P. El Reto de Innovar en Tecnología Educando en el Desarrollo Sostenible; Universidad Politécnica de Madrid: Madrid, Spain, 2019.

89. Chóliz, M.; Villanueva, V.; Chóliz, M.C. Ellos, ellas y su móvil: Uso, abuso (¿y dependencia?) del teléfono móvil en la adolescencia. Rev. Esp. Drogodepend. 2009, 34, 74-88.

90. Santana-Vega, L.E.; Gómez-Muñoz, A.M.; Feliciano-García, L. Uso problemático del móvil, fobia a sentirse excluido y comunicación familiar de los adolescentes. Comunicar 2019, 27, 39-47. [CrossRef]

91. Rieckmann, M. Learning to transform the world: Key competencies in Education for Sustainable Development. In Issues and Trends in Education for Sustainable Development; Leicht, A., Heiss, J., Byund, W.J., Eds.; UNESCO Publishing: Paris, Italy, 2018 ; pp. 39-61.

92. Wals, A.E.J. Más Allá de Dudas no Razonables. Educación y Aprendizaje para la Sostenibilidad Socioecológica en el Antropoceno; Universidad de Wageningen: Wageningen, The Netherlands, 2015.

93. Wals, A.E.; Lenglet, F. Sustainability citizens: Collaborative and disruptive social learning. In Sustainability Citizenship in Cities. Theory and Practice; Horne, R., Fien, J., Beza, B., Nelson, A., Eds.; Routledge: London, UK, 2016; pp. 72-86.

94. UNESCO. Rethinking Education. Towards a Global Common Good? Available online: https://acortar.link/Ma7do (accessed on 28 May 2020). 